\title{
A presentation of the differences between the sheep and goat genetic maps
}

\author{
Jillian F. MADDOX* \\ Centre for Animal Biotechnology, The University of Melbourne, Victoria 3010, Australia
}

(Accepted: 1 September 2004)

\begin{abstract}
The current autosomal version (4.2) of the sheep genetic map comprises 1175 loci and spans $\sim 3540 \mathrm{cM}$. This corresponds to almost complete coverage of the sheep genome. Each chromosome is represented by a single linkage group, with the largest gap between adjacent loci being $19.8 \mathrm{cM}$. In contrast the 1998 goat genetic map (the most recently published) is much less well developed spanning $2737 \mathrm{cM}$ and comprising only 307 loci. Only one of the goat chromosomes appears to have complete coverage (chromosome 27), and 16 of the chromosomes are comprised of two or more linkage groups, or a linkage group and one or more unlinked markers. The two maps share 218 loci, and the maps have been aligned using the shared loci as reference points. Overall there is good agreement between the maps in terms of homologous loci mapping to equivalent chromosomes in the two species, with only four markers mapping to nonequivalent chromosomes. However, there are lots of inversions in locus order between the sheep and goat chromosomes. Whilst some of these differences in locus order may be genuine, the majority are likely to be a consequence of the paucity of genetic information for the goat map.
\end{abstract}

genetic / linkage / sheep / goat / map

\section{INTRODUCTION}

Fossil evidence suggests that the sheep and goat lineages diverged approximately five to eight million years ago, and that the Caprinae lineage itself diverged from that of Bovinae 17 to 20 million years ago. Despite this difference in divergence times, the number of chromosomes is the same for cattle and goats, each of which have 29 acrocentric autosomes, as compared to the sheep which has only 26 autosomes (three metacentric, 23 acrocentric). The domestic sheep karyotype appears to have resulted from three Robertsonian translocation events resulting in sheep (OAR) chromosome 1 being equivalent to goat (CHI) and cattle (BTA) chromosomes 1 and 3, OAR 2 being equivalent to CHI/BTA 2 and 8, and OAR 3 being equivalent to CHI/BTA 5

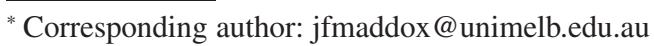


and 11 (Fig. 1). Other features of gross chromosomal morphology, such as the architecture of the X chromosome and that of OAR 9/CHI 14, are similar for sheep and goats, but differ from cattle [7, 11, 14, 17, 22, 27]. The similarity between the goat and sheep karyotypes is further evidenced by reports of natural matings between rams and does producing hybrid offspring, with at least one instance of such a mating generating a female offspring that was shown to be fertile when mated to a ram $[16,24,25]$.

For both sheep and goats much of the impetus for genetic map development has come from the linkage mapping of traits of interest. In the case of goats, the reason for developing a genetic map was to map the locus responsible for the Polled Intersex Syndrome [26], and relatively little genetic map development has occurred for goats since this locus was mapped. Initially, much of the work on the sheep genetic map was aimed at identifying loci responsible for fertility traits such as Inverdale and Booroola [12,20]. More recently mapping efforts in sheep have also included searches for traits affecting meat, wool, and disease susceptibility and resistance $[4,5,8,15]$. This focus on mapping specific traits has lead to genetics maps that have uneven distributions of markers on chromosomes. Not surprisingly, regions disproportionately rich in markers are found in areas of the maps that are near traits of interest, e.g., chromosome 6 with Booroola and Spider Lamb Syndrome, chromosome 18 and callipyge/Carwell, and the X chromosome and Inverdale in sheep; and chromosome 1 with Polled Intersex Syndrome in goats [6, 12, 21, 29, 30]. More recently development of the sheep genetic map has focused on increasing the number of mapped markers that are associated with genes so as to increase the number of links to maps of other species such as humans and mice [18]. This has mainly been done by the development and mapping of microsatellites that are associated with genes, and by performing blast searches to identify genes that are associated with previously mapped anonymous microsatellites. A brief summary of the development of the sheep and goat linkage maps is given in Table I.

\section{MATERIAL AND METHODS}

\section{Construction of SheepMap 4.2 and alignment of sheep and goat genetic maps}

The methods used for all aspects of map construction of the sheep genetic map are described in [17]. The current version (4.2) best positions sheep genetic map [3] was aligned with the most recent goat linkage map [23]. 
Table I. Map and population statistics for sheep and goat maps.

\begin{tabular}{|c|c|c|c|c|c|}
\hline Map & Size (cM) & Map Type & $\begin{array}{c}\text { Herd/Flock }^{\#} \\
\text { Number of } \\
\text { Animals }\end{array}$ & $\begin{array}{c}\text { Number of } \\
\text { Markers }\end{array}$ & Reference \\
\hline Goat 1996 & 2300 & Male & $\begin{array}{c}\text { INRA } \\
575\end{array}$ & 219 & {$[27]$} \\
\hline Goat 1998 & 2737 & Male & $\begin{array}{c}\text { INRA } \\
575\end{array}$ & $307^{*}$ & [23] \\
\hline SheepMap 1 & 2070 & Both sexes & $\begin{array}{c}\text { IMF } \\
127\end{array}$ & 246 & [7] \\
\hline SheepMap 2 & 3063 & Both sexes & $\begin{array}{c}\text { IMF, MARC } \\
127+295\end{array}$ & 519 & [9] \\
\hline SheepMap 3 & $\sim 3600$ & Both sexes & $\begin{array}{l}\text { IMF } \\
127\end{array}$ & 1093 & [17] \\
\hline SheepMap 4.2 & $\sim 3600$ & Both sexes & $\begin{array}{c}\text { IMF } \\
127\end{array}$ & 1251 & [3] \\
\hline Sheep X, Y & 141.9 & Both sexes & $\begin{array}{c}\text { XMF } \\
480\end{array}$ & 21 & [11] \\
\hline
\end{tabular}

* 15 markers were mapped by fluorescent in situ hybridisation.

\#The INRA goat herd consists of 12 2-generation families, the IMF (international mapping flock) consists of 93 -generation full-sibling families, the MARC (Meat Animal Research Centre) flock consists of 4 2-generation families, and the XMF (X mapping flock) consists of 143 -generation half-sibling families.

\section{RESULTS}

Details of the current sheep genetic map can be found on the Australian Gene Mapping Web Site [3] and in Table II. There are 1251 markers representing 1232 loci on the current sheep genetic map, and the comprehensive sex averaged genetic map spans approximately $3630 \mathrm{cM}$. This corresponds to virtually complete coverage of the sheep genome. Each chromosome is represented by a single linkage group with the largest gap between adjacent loci being $19.8 \mathrm{cM}(\backslash B M C 1222-\backslash B M 8115$ on chr 13 and $C G B P-\backslash U R B 031$ on chr 23). There are 74 regions on this map where the closest distance between adjacent markers is between 10 and $20 \mathrm{cM}$.

In contrast, the goat map is quite primitive. The only genetic map available is a male map that spans $2737 \mathrm{cM}$ and comprises 307 markers. Only one of the chromosomes appears to have complete coverage (chromosome 27), with 16 of the chromosomes being comprised of 2 or more linkage groups, or a linkage group and one or more unlinked markers. 
Table II. Chromosomal statistics and comparisons for the sheep best positions linkage map v 4.2.

\begin{tabular}{|c|c|c|c|c|c|c|c|}
\hline \multirow[b]{2}{*}{ OAR } & \multicolumn{3}{|c|}{ Length of chromosome } & \multirow{2}{*}{$\begin{array}{c}\text { Number } \\
\text { of sheep } \\
\text { loci }\end{array}$} & \multirow{2}{*}{$\begin{array}{l}\text { Number of } \\
\text { loci with } \\
\text { highly } \\
\text { polymorphic } \\
\text { markers }{ }^{\#}\end{array}$} & \multirow{2}{*}{$\begin{array}{l}\text { Number of } \\
\text { loci on } \\
\text { both sheep } \\
\text { linkage and } \\
\text { human } \\
\text { maps }\end{array}$} & \multirow{2}{*}{$\begin{array}{c}\text { Number of } \\
\text { loci mapped } \\
\text { by linkage } \\
\text { analysis in } \\
\text { both sheep } \\
\text { and goats }\end{array}$} \\
\hline & $\begin{array}{c}\text { Sex Av } \\
\mathrm{cM}\end{array}$ & $\begin{array}{c}\text { Female } \\
\mathrm{cM}\end{array}$ & $\begin{array}{l}\text { Male } \\
\mathrm{cM}\end{array}$ & & & & \\
\hline 1 & 347.4 & 326.6 & 371.7 & 122 & 60 & 25 & $23^{*}$ \\
\hline 2 & 308.4 & 289.5 & 328.5 & 106 & 59 & 24 & 21 \\
\hline 3 & 313.4 & 305.1 & 319.6 & 103 & 45 & 27 & 18 \\
\hline 4 & 151.9 & 136.2 & 159.9 & 44 & 18 & 12 & 9 \\
\hline 5 & 156.9 & 154.0 & 168.8 & 46 & 12 & 12 & 8 \\
\hline 6 & 156.7 & 132.2 & 178.9 & 64 & 26 & 25 & 7 \\
\hline 7 & 145.9 & 141.0 & 250.9 & 55 & 25 & 16 & 8 \\
\hline 8 & 132.8 & 133.7 & 131.5 & 41 & 22 & 8 & 7 \\
\hline 9 & 126.9 & 118.5 & 134.7 & 43 & 32 & 8 & 12 \\
\hline 10 & 105.1 & 102.2 & 108.7 & 34 & 19 & 2 & 6 \\
\hline 11 & 112.4 & 106.6 & 120.4 & 41 & 16 & 19 & 7 \\
\hline 12 & 113.1 & 98.2 & 127.7 & 33 & 16 & 7 & 5 \\
\hline 13 & 128.3 & 128.0 & 128.7 & 35 & 18 & 6 & 4 \\
\hline 14 & 119.9 & 98.4 & 141.3 & 40 & 26 & 8 & 8 \\
\hline 15 & 124.4 & 100.9 & 145.9 & 47 & 25 & 19 & 7 \\
\hline 16 & 86.2 & 78.9 & 92.4 & 35 & 20 & 6 & 10 \\
\hline 17 & 130.7 & 118.5 & 143.6 & 41 & 20 & 9 & 9 \\
\hline 18 & 131.5 & 115.3 & 151.7 & 46 & 22 & 8 & 7 \\
\hline 19 & 73.3 & 67.8 & 85.3 & 27 & 15 & 6 & 6 \\
\hline 20 & 89.6 & 80.4 & 103.0 & 32 & 13 & 10 & 7 \\
\hline 21 & 74.2 & 59.2 & 87.1 & 26 & 15 & 6 & 4 \\
\hline 22 & 82.9 & 60.6 & 98.7 & 22 & 14 & 3 & 6 \\
\hline 23 & 95.5 & 84.1 & 106.6 & 21 & 10 & 7 & 5 \\
\hline 24 & 89.4 & 89.2 & 90.1 & 31 & 11 & 12 & 3 \\
\hline 25 & 69.9 & 56.2 & 78.8 & 20 & 11 & 4 & 2 \\
\hline 26 & 71.1 & 57.3 & 85.9 & 20 & 12 & 2 & 9 \\
\hline $\begin{array}{c}\text { Total } \\
\text { autosomal }\end{array}$ & 3537.8 & 3238.6 & 3940.4 & 1175 & 562 & 291 & 218 \\
\hline$X$ & 90.8 & 132.4 & 58.6 & 57 & 20 & 10 & \\
\hline
\end{tabular}

*Two markers from the PISRT1 region (LSCV86 and LSCV210) have been linkage mapped in both sheep and goats however these markers are not on the 1998 goat map [23].

${ }^{\#}$ PIC of at least 0.7 or at least 8 alleles. 
Table III. Mapping discrepancies between the genetic maps of sheep and goats.

\begin{tabular}{lcccl}
\hline Marker & OAR & $\begin{array}{c}\text { Predicted } \\
\text { CHI }\end{array}$ & Actual CHI & Comment \\
\hline OarCP9 & 9 & 14 & $16^{*}$ & $\begin{array}{l}\text { Goat product sequence }>90 \% \text { similar } \\
\text { to sheep sequence }\end{array}$ \\
OarHH22 & 21 & 29 & 16 & Cattle position equivalent to sheep \\
BM723 & 23 & 24 & $3^{*}$ & Cattle position equivalent to goat \\
MAF48 & X & X & 19 & \\
\hline *Also mapped physically. & &
\end{tabular}

The sheep and goat genetic maps have 218 loci in common (Fig. 1, Tab. II). Overall there is good agreement between the maps in terms of loci mapping to equivalent chromosomes in the two species. There are only four markers that map to non-equivalent chromosomes (Tab. III). However, as can be seen in Figure 1, there are lots of inversions in locus order between sheep and goat chromosomes.

Both the sheep and goat maps have been mapped using a mixture of sheep, cattle and goat markers. There are 50 markers of goat origin on the sheep genetic map, 531 sheep markers and 700 cattle markers. The goat genetic map comprises 41 goat markers, 49 sheep markers and 217 cattle markers.

There are 497 links between the current sheep genetic map and the MARC 2003 cattle genetic map [19], and 186 links between the goat and cattle genetic maps. The alignment between the sheep and cattle chromosomes on the genetic maps is much better than that for the sheep and goat genetic maps with a much lower proportion of rearrangements in locus order (data not shown, see sheepcattle comparisons on [3]).

Homologous human loci can be identified for 291 of the loci on the current sheep genetic map (Tab. I), and for 24 of the loci on the goat genetic map. This allows links to be made between the human sequence map and the sheep and goat genetic maps, which enable predictions of the positions of non mapped loci in sheep and goats.

\section{DISCUSSION}

The large proportion of shared markers on the sheep, goat and cattle genetic maps makes it relatively easy to align the maps. In contrast to the good agreement in locus order between the sheep and cattle maps there are many rearrangements in order between these maps and the goat map. It is likely that many of the discrepancies in order between the goat map and the other maps 


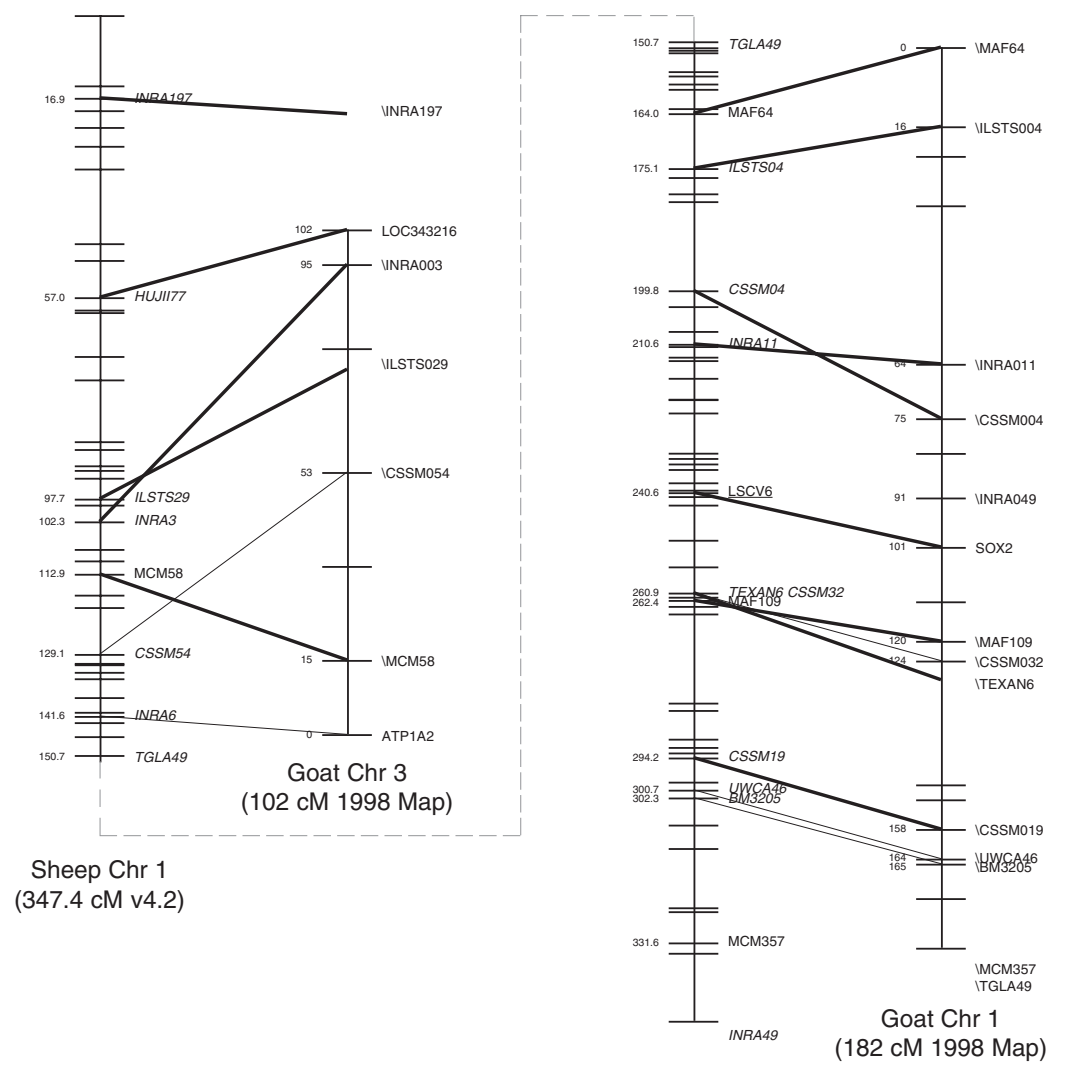

Figure 1. This figure shows the alignment of chromosome 1 from sheep and goat, as an example for the complete alignment of the current sheep linkage map (v 4.2) with the 1998 goat linkage map [23], which can be consulted at www.edpsciences.org/gse. Locus codes, marker names and position details are given only for markers that have been mapped by linkage analysis in both sheep and goats. Marker names are indicated beside sheep chromosomes and locus codes are given beside goat chromosomes. Horizontal lines on each chromosome are used to indicate the positions of all markers that have been mapped in sheep and goat. Cattle markers are indicated by italics, goat markers are underlined and sheep markers are indicated in normal text. ESTs are prefaced by a $\sim$, anonymous loci are prefaced by a $\backslash$ [1]. Loci that have been linkage mapped in sheep, but not on the IMF, are indicated either at the bottom of the appropriate chromosome or at their estimated position on the chromosome. The INRA197, MCM357 and TGLA49 markers did not link to other markers on the goat map. The $\backslash$ INRA197 locus has been physically mapped in goats and its physical position (3q36) indicates that it maps to the bottom of chromosome 3 (hence its placement in this figure). Thick lines between chromosomes are used to indicate loci that are on the sheep framework map, thin lines indicate loci where the position on the sheep map is supported by odd scores of less than 1000:1. 
are artefacts. The goat genetic map is less robust, than the sheep and cattle maps, as a consequence of being constructed from a smaller number of markers. In addition, the amount of error checking that has taken place for the goat map is likely to be considerably less than has been done for either the sheep or cattle maps. However, it is possible that some of the discrepancies in chromosomal locations or locus order may be genuine. Given that the sequence of the goat product obtained using the OarCP9 primers was more than $90 \%$ similar to that of sheep [27], it is possible that homologous products are amplified in sheep and goats using these primers, and that the discrepancy in the chromosomal locations of these loci in sheep and goats is real. Likewise, the relative inversion of the order of the segment comprising IL2RA- ILSTS59 on chromosome 13 may be real. This order is based on cytogenetic mapping in the goat as there is insufficient linkage information to determine the order on the goat chromosome.

The lack of development of the goat map is not surprising given that the goat map was developed specifically for a genome screen to map a single Mendelian trait, and that the region containing this locus was identified without the need for a full genome scan [26]. The only region mapped in depth on the goat genetic map is the region on chromosome 1 flanking the PISRT1 locus $[21,28]$. In contrast, the sheep genetic map has benefited from being needed for genome screens for a variety of traits.

There has been a relatively greater effort in the goat to cytogenetically map loci [23], with almost 500 loci mapped cytogenetically [13]. This contrasts with the sheep where only about 350 loci have been cytogenetically mapped [2]. One hundred and thirty-two of the microsatellites (43\%) on the goat genetic map have also been cytogenetically mapped, and 143 loci (12\%) on the sheep map have also been cytogenetically mapped. In both sheep and goats the majority of the cytogenetically mapped loci are type I rather than type II (anonymous) loci, and thus the cytogenetically mapped loci have a greater proportion of links to homologues on the human sequence map than do the loci on the genetic maps.

To date, five mutations for single gene traits have been successfully mapped in sheep and goats following the use of the genetic maps of these species. These are the Spider Lamb [6], Booroola [30], Callipyge [10] and Inverdale [12] traits in sheep, and the Polled Intersex trait in goats [21]. Many QTL regions have been identified for a vast range of traits from genome screens in sheep. Whilst some of these QTL studies have advanced to the fine mapping stage, none of the sheep QTL studies has yet resulted in the identification of a causative mutation. Further genetic map development is needed to improve the efficiency 
of genome screens in sheep and goats especially in terms of a more uniform coverage of map regions with highly polymorphic markers. It will also be vital to increase the number of links between the sheep and goat genetic maps and the sequence maps of other species, so as to be better able to use comparative information to assist with genome screens for traits of interest in sheep and goats.

\section{ACKNOWLEDGEMENTS}

The author thanks Meat and Livestock Australia for financial support and AgResearch New Zealand for access to the International Mapping Flock.

\section{REFERENCES}

[1] Andresen E., Broad T.E., Brown S., Cooper D.W., Distasio L., Dolling C.H.S., Fleet M., Hill D.F., Lauvergne J.J., Lundie R.S., Maddox J., Nicholas F.W., Rae A.L., Renieri C., Sponenberg D.P., Tucker E.M., Revised guidelines for gene nomenclature in ruminants 1993, Genet. Sel. Evol. 27 (1995) 89-93.

[2] ArkDB Sheep Public Database, http://www.thearkdb.org/browser?species=sheep [consulted 5 October 2003].

[3] Australian Sheep Gene Mapping Web Site, http://rubens.its.unimelb.edu.au/ $\sim$ jillm/jill.htm [consulted 5 October 2003].

[4] Beh K.J., Hulme D.J., Callaghan M.J., Leish Z., Lenane I., Windon R.G., Maddox J.F., A genome scan for quantitative trait loci affecting resistance to Trichostrongylus colubriformis in sheep, Anim. Genet. 33 (2002) 97-106.

[5] Cockett N.E., Jackson S.P., Shay T.L., Nielsen D., Moore S.S., Steele M.R., Barendse W., Green R.D., Georges M., Chromosomal localization of the callipyge gene in sheep (Ovis aries) using bovine DNA markers, Proc. Natl. Acad. Sci., USA 91 (1994) 3019-3023.

[6] Cockett N.E., Shay T.L., Beever J.E., Nielsen D., Albretsen J., Georges M., Peterson K., Stephens A., Vernon W., Timofeevskaia O., South S., Mork J., Maciulis A., Bunch T.D., Localization of the locus causing Spider Lamb Syndrome to the distal end of ovine Chromosome 6, Mamm. Genome 10 (1999) 35-38.

[7] Crawford A.M., Dodds K.G., Pierson C.A., Ede A.J., Montgomery G.W., Garmonsway H.G., Beattie A.E., Davies K., Maddox J.F., Kappes S.W., Stone R.T., Nguyen T.C., Penty J.M., Lord E.A., Broom J.E., Buitkamp J., Schwaiger W., Epplen J.T., Matthew P., Matthews M.E., Hulme D.J., Beh K.J., McGraw R.A., Beattie C.W., An autosomal genetic linkage map of the sheep genome, Genetics 140 (1995) 703-724.

[8] Crawford A.M., Searching for disease resistance QTL, in: XXVI International Conference on Animal Genetics, 9-14 August 1998, International Society for Animal Genetics, Auckland, New Zealand, pp. 7-8. 
[9] de Gortari M.J., Freking B.A., Cuthbertson R.P., Kappes S.M., Keele J.W., Stone R.T., Leymaster K.A., Dodds K.G., Crawford A.M., Beattie C.W., A second-generation linkage map of the sheep genome, Mamm. Genome 9 (1998) 204-209.

[10] Freking B.A., Murphy S.K., Wylie A.A., Rhodes S.J., Keele J.W., Leymaster K.A., Jirtle R.L., Smith T.P., Identification of the single base change causing the callipyge muscle hypertrophy phenotype, the only known example of polar overdominance in mammals, Genome Res. 12 (2002) 1496-1506.

[11] Galloway S.M., Hanrahan V., Dodds K.G., Potts M.D., Crawford A.M., Hill D.F., A linkage map of the ovine $\mathrm{X}$ chromosome, Genome Res. 6 (1996) 667-677.

[12] Galloway S.M., McNatty K.P., Cambridge L.M., Laitinen M.P., Juengel J.L., Jokiranta T.S., McLaren R.J., Luiro K., Dodds K.G., Montgomery G.W., Beattie A.E., Davis G.H., Ritvos O., Mutations in an oocyte-derived growth factor gene (BMP15) cause increased ovulation rate and infertility in a dosage-sensitive manner, Nat. Genet. 25 (2000) 279-283.

[13] GoatMap database, http://locus.jouy.inra.fr/cgi-bin/lgbc/mapping/common/ intro2.pl?BASE=goat [consulted 5 October 2003].

[14] Hassanane M.S., Chaudhary R., Chowdhary B.P., Microdissected bovine X chromosome segment delineates homoeologous chromosomal regions in sheep, goat and buffalo, Chromosome Res. 6 (1998) 213-217.

[15] Henry H.M., Dodds K.G., Wuliji T., Jenkins Z.A., Beattie A.E., Montgomery G.W., A genome screen for QTL for wool traits in a Merino X Romney backcross flock, in: 6th World Cong. Genet. Appl. Livest. Prod., 11-16 January 1998, University of New England, Armidale, pp. 433-436.

[16] Letshwenyo M., Kedikilwe K., Goat-sheep hybrid born under natural conditions in Botswana, Vet. Record 146 (2000) 732-734.

[17] Maddox J.F., Davies K.P., Crawford A.M., Hulme D.J., Vaiman D., Cribiu E.P., Freking B.A., Beh K.J., Cockett N.E., Kang N., Riffkin C.D., Drinkwater R., Moore S.S., Dodds K.G., Lumsden J.M., van Stijn T.C., Phua S.H., Adelson D.L., Burkin H.R., Broom J.E., Buitkamp J., Cambridge L., Cushwa W.T., Gerard E., Galloway S.M., Harrison B., Hawken R.J., Hiendleder S., Henry H.M., Medrano J.F., Paterson K.A., Schibler L., Stone R.T., van Hest B., An enhanced linkage map of the sheep genome comprising more than 1000 loci, Genome Res. 11 (2001) 1275-1289.

[18] Maddox J.F., Franklin I.R., Bottema C.D.K., De Silva U., Adelson D.L., Nattrass G., Identification of homologies between the sheep linkage map and maps of other species, in: XIX International Congress of Genetics, 6-11 July 2003, International Genetics Federation, Melbourne, Australia, p. 103.

[19] MARC Cattle Map, http://www.marc.usda.gov/genome/genome.html [consulted 5 October 2003].

[20] Montgomery G., Lord E., Penty J., Dodds K., Broad T., Cambridge L., Sunden S., Stone R., Crawford A., The Booroola fecundity (FecB) gene maps to sheep chromosome 6, Genomics 4 (1994) 410-414. 
[21] Pailhoux E., Vigier B., Chaffaux S., Servel N., Taourit S., Furet J.P., Fellous M., Grosclaude F., Cribiu E.P., Cotinot C., Vaiman D., A 11.7-kb deletion triggers intersexuality and polledness in goats, Nat. Genet. 29 (2001) 453-458.

[22] Ponce de Leon F.A., Ambady S., Hawkins G.A., Kappes S.M., Bishop M.D., Robl J.M., Beattie C.W., Development of a bovine X chromosome linkage group and painting probes to assess cattle, sheep, and goat X chromosome segment homologies, Proc. Natl. Acad. Sci., USA 93 (1996) 3450-3454.

[23] Schibler L., Vaiman D., Oustry A., Giraud-Delville C., Cribiu E.P., Comparative gene mapping a fine-scale survey of chromosome rearrangements between ruminants and humans, Genome Res. 8 (1998) 901-915.

[24] Stewart-Scott I.A., Pearce P.D., Dewes H.F., Thompson J.W.L., A case of a sheep-goat hybrid in New Zealand, N. Z. Vet. J. 38 (1990) 7-9.

[25] Tucker E.M., Denis B., Kilgour L., Blood genetic markers of a sheep-goat hybrid and its back-cross offspring, Anim. Genet. 20 (1989) 179-186.

[26] Vaiman D., Koutita O., Oustry A., Elsen J.M., Manfredi E., Fellous M., Cribiu E.P., Genetic mapping of the autosomal region involved in XX sexreversal and horn development in goats., Mamm. Genome 7 (1996) 133-137.

[27] Vaiman D., Schibler L., Bourgeois F., Oustry A., Amigues Y., Cribiu E.P., A genetic linkage map of the male goat genome, Genetics 144 (1996) 279-305.

[28] Vaiman D., Pailhoux E., Schibler L., Oustry A., Chaffaux S., Cotinot C., Fellous M., Cribiu E.P., Genetic mapping of the polled/intersex locus (PIS) in goats, Theriogenology 47 (1997) 103-109.

[29] Vaiman D., Schibler L., Oustry-Vaiman A., Pailhoux E., Goldammer T., Stevanovic M., Furet J.P., Schwerin M., Cotinot C., Fellous M., Cribiu E.P., High-resolution human/goat comparative map of the goat polled/intersex syndrome (PIS) the human homologue is contained in a human YAC from HSA3q23, Genomics 56 (1999) 31-39.

[30] Wilson T., Wu X.Y., Juengel J.L., Ross I.K., Lumsden J.M., Lord E.A., Dodds K.G., Walling G.A., McEwan J.C., O’Connell A.R., McNatty K.P., Montgomery G.W., Highly prolific Booroola sheep have a mutation in the intracellular kinase domain of bone morphogenetic protein IB receptor (ALK-6) that is expressed in both oocytes and granulosa cells, Biol. Reprod. 64 (2001) 1225-1235. 